\title{
Synthesis and Characterization of New Mannich Bases Derived from 7-hydroxy-4-methyl Coumarin
}

\author{
Abdel - Amir M. Fenjan* \\ Inas Salim Mahdi** \\ *Department of Chemistry, College of Science for Women, University of Baghdad, \\ Baghdad, Iraq. \\ **Department of Fundamental Science, College of Agriculture, University of \\ Baghdad, Baghdad, Iraq.
}

E-mail: amirfenjan@yahoo.com

Received 16/9/2015

Accepted 20/12/2015

\section{(1) $9 \odot$}

NoDerivatives 4.0 International Licens

\begin{abstract}
:
Coumarin is a natural substance isolated from different plants. It belonges to a group of benzobyrones which consists of a benzene ring joined to a pyrone nucleus. In the present research, a new series of coumarin derivatives were formed. Compound (1) (7-hydroxy-4-methyl Coumarin) was converted into 4-methylquinolin-2(H) derivative (2) by reaction with acetamide, and then reaction of (2) with thiosemicarbazide in ethanol leads to the synthesize of hydrazincarbothioamide derivative (3). The reaction of (3) with ethylchloroacetate in presence of sodium acetate leads to closure ring to get [(1-(5-oxo-2-thioxoimidazolidin-1-ylimino) ethyl)]quinolin-2(1H)-one (4). Mannich bases were prepared through the reaction of (4) with primary amines to form compounds (5-6). New coumarin derivatives were characterized by their physical properties and various spectral analysis like: FTIR, ${ }^{1}$ HNMR spectra and GC-Mass spectrum for some of them.
\end{abstract}

Key words: coumarin, thioxoimidazolidin, methylquinolin.

\section{Introduction:}

Coumarin is categorized as a member of the benzopyrone family (compounds which consist of a benzene ring joined to a pyrone ring) [1]. Coumarins acquired their class name to "Coumarou", the vernacular name of the tonka bean which coumarin itself was isolated in 1820 [2]. Coumarins have a great biological activities such as: anti-microbial, anti-viral, antiinflammatory, anti-malarial, anticoagulant, anti-oxidant and analgesic, which makes these compounds attractive for more derivatization and screening.The pharmacokinetics of coumarin including the secretion of various metabolites were explained many years. Coumarin is readily and nearly completely metabolized with little unchanged compound excreted [3]. The current research aimed to synthesize new heterocyclic compounds derived from 7-hydroxy-4-methyl-coumarin containing acetyl, hydrazine 
The $2^{\text {nd }}$ National Conference of Chemistry

carbothioamide, thioxo- imidazolidin moieties.

\section{Materials and Methods:}

Initial Chemical Compounds were obtaind from BDH, Merck and Fluka companies.The mellting point was determind in an capillary tubes on Sturat Scientific melting point SMPLU-K and are uncorrected. Infrared spectra was recorded on Shimadzu FTIR (8300) spectrophotometer by using $\mathrm{KBr}$ pellet technique in Ibn Sina State Company (ISSC). ${ }^{1}$ HNMR spectra was recorded on B Bruker DMX -500 NMR spectrophotometer in Al- al Bayt University (Jordan) $\}$ in frequency 300 $\mathrm{MHz}$, using TMS as the internal standard in (DMSO- $\mathrm{d}_{6}$ ). Mass spectra was recorded on Ultra Shimadza (GCHS-QP 2010) in Al-Mustansiriyh University.

\section{- Preparation of 7-Hydroxy-4- Methyl Coumarin [4] (1)}

Powdered resorcinol $(3.7 \mathrm{~g}, 0.0336 \mathrm{~mol})$ was added to $(4.4 \mathrm{ml}$, $3.46 \mathrm{~mol})$ of ethyl acetoacetate and stirred, then it was added slowly to (15 $\mathrm{ml}$ ) of conc. $\mathrm{H}_{2} \mathrm{SO}_{4}$ with stirring about (5-10) ${ }^{\circ} \mathrm{C}$ for 30 mins. then left for $1 \mathrm{hr}$. Then the mixture was poured into crushed ice, the precipitate was filtered, dried and recrystallized from ethanol.

\section{- Preparation of 1-acetyl-7-} hydroxy-4-methyl quinolin2(1H)-one [5] (2)

A mixture of compound [1] (7.04g , $0.04 \mathrm{~mol})$ and $(2.36 \mathrm{~g}, 0.04 \mathrm{~mol})$ acetamide in $(40 \mathrm{ml})$ dry benzene was refluxed for 8hrs. then filtered dried and recrystallized from chloroform.

\section{-Preparation of 2-(1-(7- hydroxy-4-methyl-2-oxo quinolin-1(2H)-yl) ethylidene) hydrazine carbothioamide [6] (3)}

A mixture of compound (2) $(1.08 \mathrm{~g}, 0.01 \mathrm{~mol})$ and thiosemicarbazide
$(0.91 \mathrm{~g}, 0.01 \mathrm{~mol})$ were dissolved in $(50 \mathrm{ml})$ ethanol and refluxed for $4 \mathrm{hrs}$. the resulting crystals cooled, filtered and washed with distilled water, dried and recrystallized from ethanol.

- Preparation of 7-hydroxy-4methyl-1-(1-(5-oxo-2-thioxo imidazolidin-1-ylimino) ethyl)quinolin-2(1H)-one [6] (4)

A mixture of compound (3) $(2.9 \mathrm{~g}, 0.01 \mathrm{~mol})$ and ethyl chloro acetate $(1.06 \mathrm{ml}, 0.01 \mathrm{~mol})$ in $(50 \mathrm{ml})$ ethanol in presence of sodium acetate $(2.46 \mathrm{~g}$ , $0.03 \mathrm{~mol}$ ) were refluxed for $6 \mathrm{hrs}$. then cooled and poured into crushed ice. The precipitate was filtered, washed with distilled water, dried and recrystallized from ethanol.

\section{- Preparation of Mannich bases} [7] (5-6)

Compound (4) $(3.17 \mathrm{~g}, 0.01 \mathrm{~mol})$ was dissolved in $(15 \mathrm{ml})$ ethanol and $(0.01 \mathrm{~mol})$ from ( $p$-bromo aniline, $p$ chloro aniline) was added slowly to reaction mixture, then add $(0.73 \mathrm{ml}$, $0.02 \mathrm{~mol}$ ) formaldehyde then refluxed for $10 \mathrm{hrs}$. After the completion of reaction, the mixture was poured into ice water and kept into refrigerator for $24 \mathrm{hrs}$. the precipitate was filtered, dried and recrystallized from ethanol.

\section{Results and Discussion:}

Treatment of ethyl acetoacetate with resorcenol in cooled medium in the presence of sulfuric acid leads to production coumarin. The new derivatives prepared following the reactions sequence depicted in Scheme(2). The structure of compounds (1-6) were confirmed by physical properties and spectral data which are listed in Table (1).

The FTIR spectrum of compound (1), Figure(1), shows the $(\mathrm{C}=\mathrm{O})$ stretching frequency near $(1678) \mathrm{cm}^{-1}$. The frequency of the $(\mathrm{C}=\mathrm{C})$ group appears at about (1597) $\mathrm{cm}^{-1}$, and absorption band at $(3155) \mathrm{cm}^{-1}$ due to 
the stretching vibration of the hydroxyl group.

Reaction of compound (1) with acetamide leads to obtain quinolin derivative (2). The FTIR spectrum of (2), Figure (2) displays absorption band of $(\mathrm{C}=\mathrm{O})$ at $(1701) \mathrm{cm}^{-1}$ acetyl and (1774) $\mathrm{cm}^{-1}$ quinolin , $(\mathrm{C}=\mathrm{C})$ at $(1616)$ $\mathrm{cm}^{-1}$ and $(\mathrm{OH})$ at $(3448) \mathrm{cm}^{-1}$.

${ }^{1} \mathrm{HNMR}$ spectrum of (2) ,Figure(6) shows ( $\delta \mathrm{ppm}): 1.64$ (s,3H, $\mathrm{CH}_{3}$ quinolin) ; 3.40 (s,3H, $\mathrm{CH}_{3}$ acetyl); $4.65(\mathrm{~s}, 1 \mathrm{H}, \mathrm{CH}$ quinolin); (7.04-8.42)(m,3H,Ar-H) ; (9.5-10.8) (b.s,1H,OH).

Refluxing of compound(2) with thiosemicarbazide leads to production compound (3). The structure of the synthesized compound (3) has been characterized by FTIR spectrum as shown in Figure(3) that shows the appearance of the $\left(\mathrm{NH}_{2}\right)$ absorption band at $(3159-3251) \mathrm{cm}^{-1},(\mathrm{NH})$ band at $(3136) \mathrm{cm}^{-1}$ and $(\mathrm{C}=\mathrm{N})$ stretching band at (1612) $\mathrm{cm}^{-1}$.

Treatment of compound (3) with ethyl chloro acetate in presence of sodium acetate afforded (4). The structure of the synthesized compound (4) has been characterized by FTIR spectrum besides the ${ }^{1}$ HNMR spectrum. The FT-IR spectrum in Figure(4) shows the absorption bands at :(3282) $\mathrm{cm}^{-1}$ for (NH) group, at (1705) $\mathrm{cm}^{-1}$ for $(\mathrm{C}=\mathrm{O})$ quinolin and $(1643) \mathrm{cm}^{-1}$ for $(\mathrm{C}=\mathrm{O})$ imidazole and at $(1620) \mathrm{cm}^{-1}$ for $(\mathrm{C}=\mathrm{N})$ group.

${ }^{1}$ HNMR spectrum of (4), Figure(7) shows $(\delta \mathrm{ppm}): 3.36\left(\mathrm{~s}, 6 \mathrm{H}, 2 \mathrm{CH}_{3}\right) ; 4.60$ (s, $1 \mathrm{H}, \mathrm{CH}_{2}$ imidazole ring);(7.06-7.95) (m,4H,Ar-H); 8.86(s,1H,NH imidazole); 9.79 (b.s, $1 \mathrm{H}, \mathrm{OH}$ ).

Condensation of compound (4) with ( $p$-bromo aniline, $p$-chloro aniline) in the presence of formaldehyde gave Mannich Bases $(5,6)$. The suggested mechanism[8] of this reaction is shown in Scheme(1). The synthesized compound (6) has been characterized by FTIR spectrum shown in Figure(5) that shows characteristic bands: at (3278) $\mathrm{cm}^{-1}$ for $(\mathrm{NH})$ group, at (1678) $\mathrm{cm}^{-1}$ for $(\mathrm{C}=\mathrm{O})$ group and at $(1651) \mathrm{cm}^{-1}$ for $(\mathrm{C}=\mathrm{N})$ group.

The mass spectrum of compound (3), Figure(8) shows the molecular ion peak at $\mathrm{m} / \mathrm{z}=292$ which is very close to the molecular formula $\mathrm{C}_{13} \mathrm{H}_{14} \mathrm{~N}_{4} \mathrm{O}_{2} \mathrm{~S}$, $\mathrm{m} / \mathrm{z}=290$

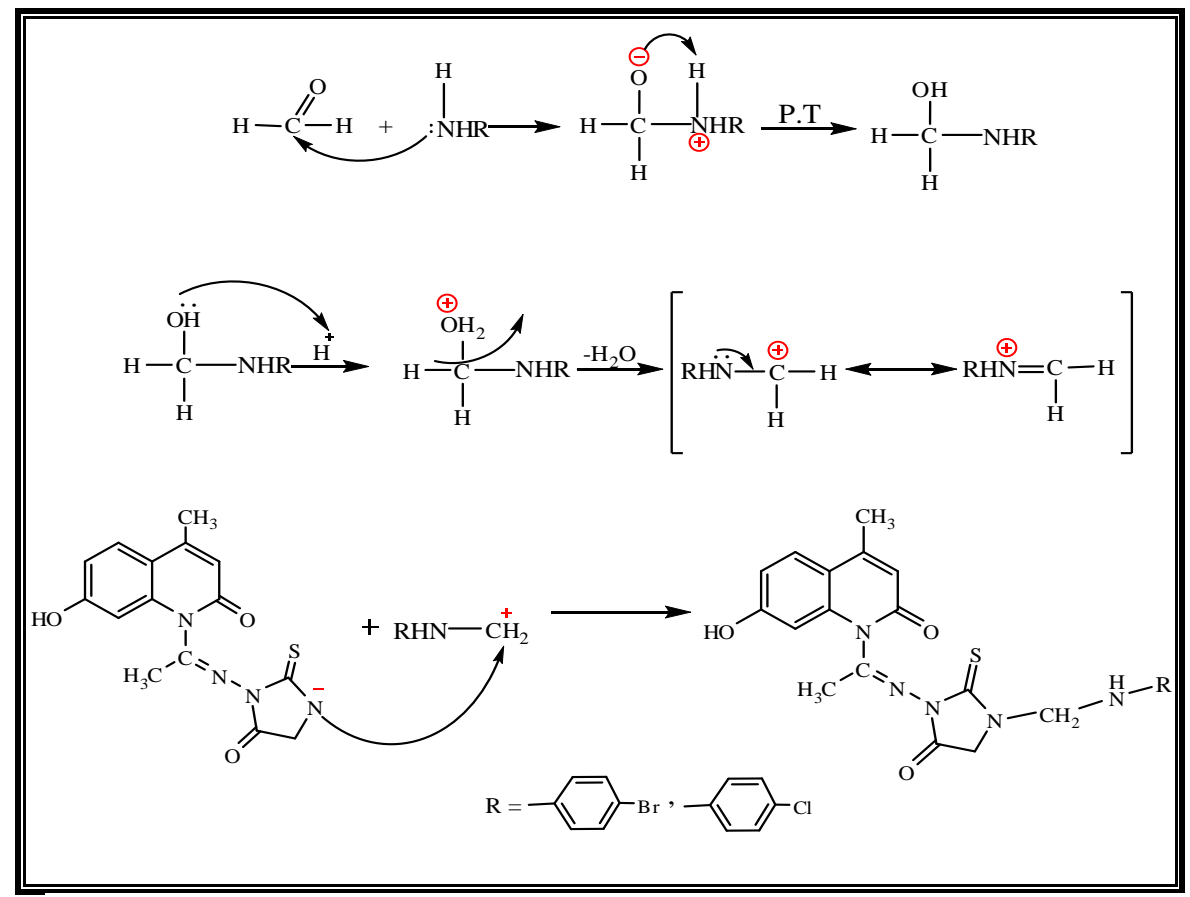

Scheme (1): Mechanism steps for the synthesis of mannich bases. 
The $2^{\text {nd }}$ National Conference of Chemistry

Table (1): physical Properties and Spectral Data of the Prepared Compounds.

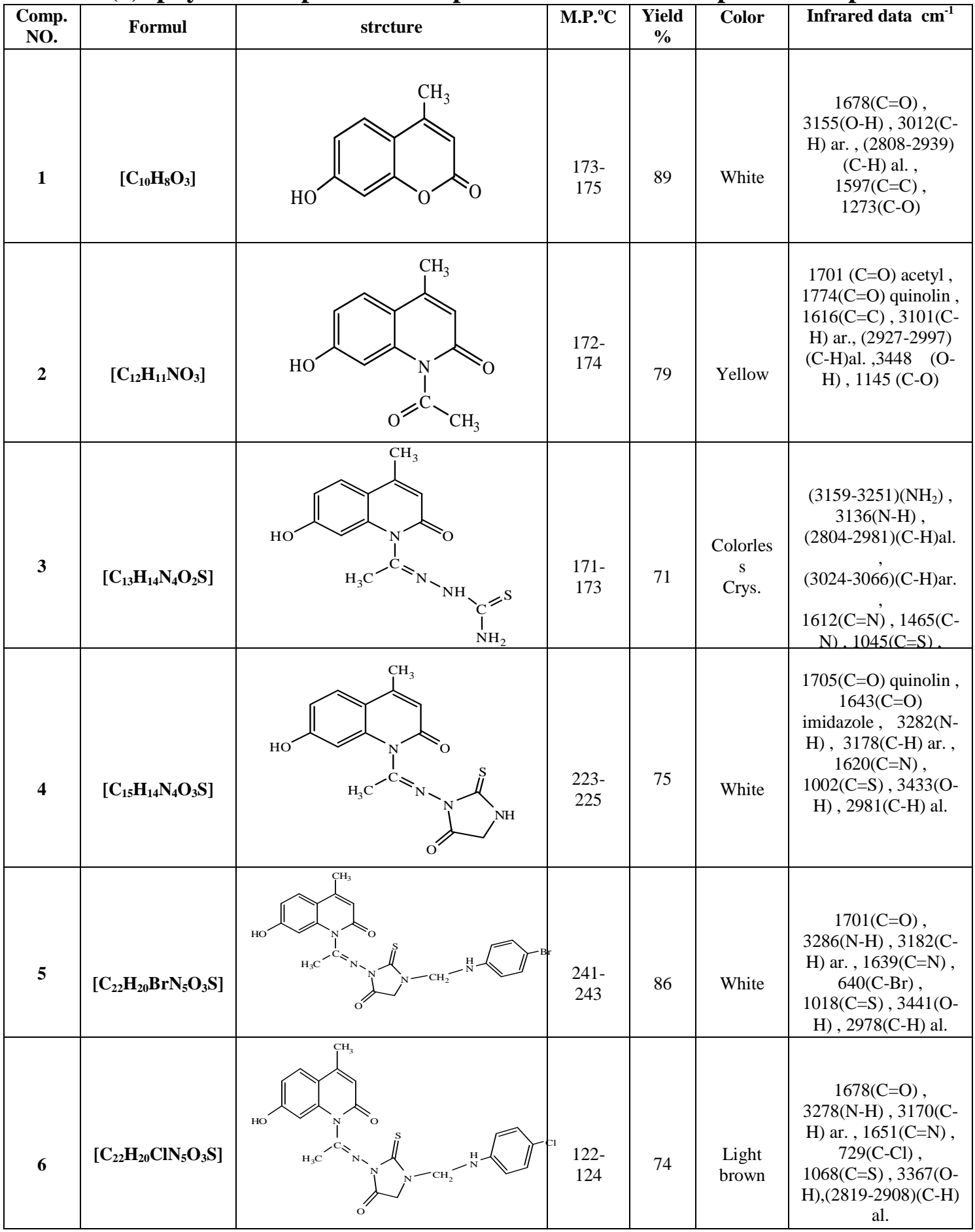

Table (2): Chemical Schiff's ${ }^{1}$ HNMR spectra

\begin{tabular}{|c|c|}
\hline $\begin{array}{c}\text { Comp. } \\
\text { NO. }\end{array}$ & ${ }^{1}$ HNMR $\left(\mathbf{D M S O}-\mathbf{d}_{\mathbf{6}}\right) \mathbf{\delta p p m}$ \\
\hline $\mathbf{2}$ & $\begin{array}{r}1.64\left(\mathrm{~s}, 3 \mathrm{H}, \mathrm{CH}_{3} \text { quinolin }\right) ; 3.40\left(\mathrm{~s}, 3 \mathrm{H}, \mathrm{CH}_{3} \text { acetyl }\right) ; 4.65(\mathrm{~s}, 1 \mathrm{H}, \mathrm{CH} \text { quinolin }) ; \\
(7.04-8.42)(\mathrm{m}, 3 \mathrm{H}, \mathrm{Ar}-\mathrm{H}) ;(9.5-10.8)(\mathrm{b} . \mathrm{s}, 1 \mathrm{H}, \mathrm{OH}) .\end{array}$ \\
\hline $\mathbf{4}$ & $3.36\left(\mathrm{~s}, 6 \mathrm{H}, 2 \mathrm{CH}_{3}\right) ; 4.60\left(\mathrm{~s}, 1 \mathrm{H}, \mathrm{CH}_{2}\right.$ imidazole ring $) ;(7.06-7.95)(\mathrm{m}, 4 \mathrm{H}, \mathrm{Ar}-\mathrm{H}) ; 8.86(\mathrm{~s}, 1 \mathrm{H}, \mathrm{NH}$ \\
imidazole $) ; 9.79(\mathrm{~b} . \mathrm{s}, 1 \mathrm{H}, \mathrm{OH})$.
\end{tabular}




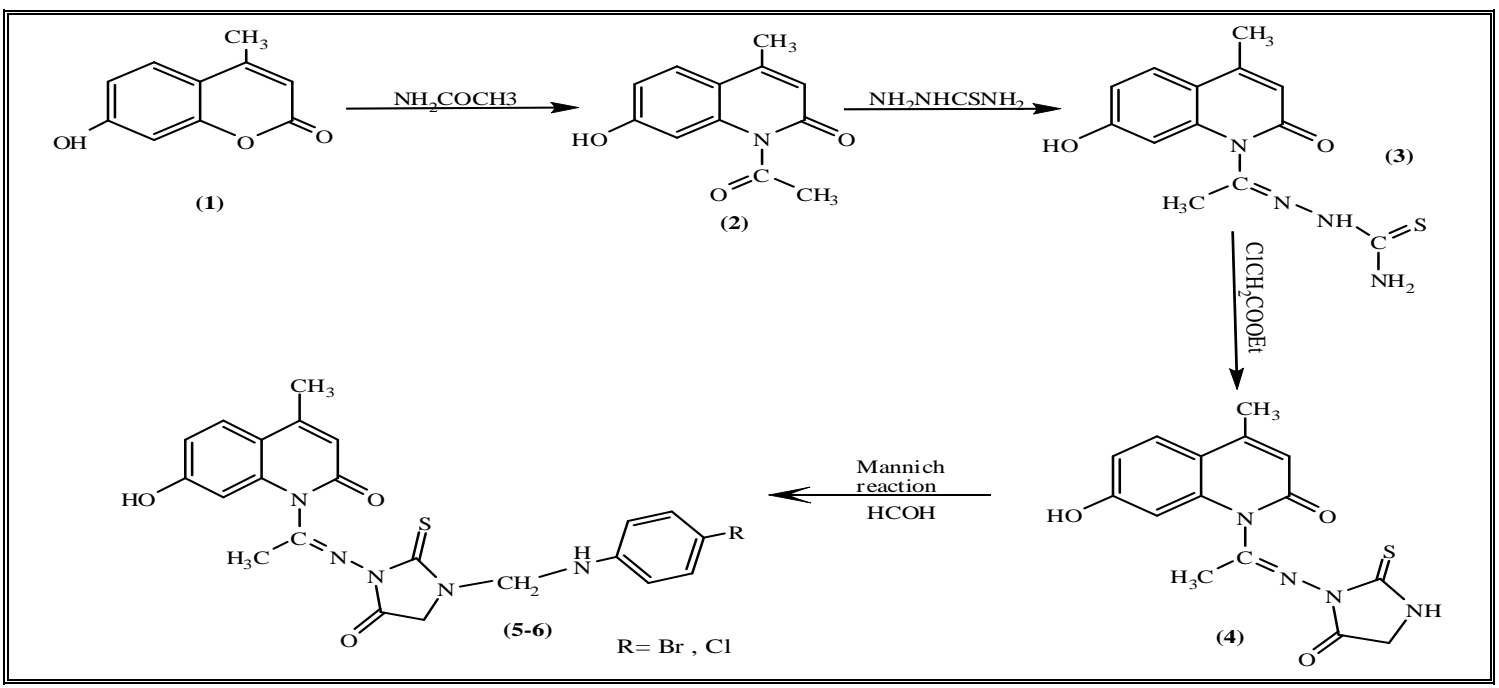

Scheme (2): Synthesis steps of new compounds.

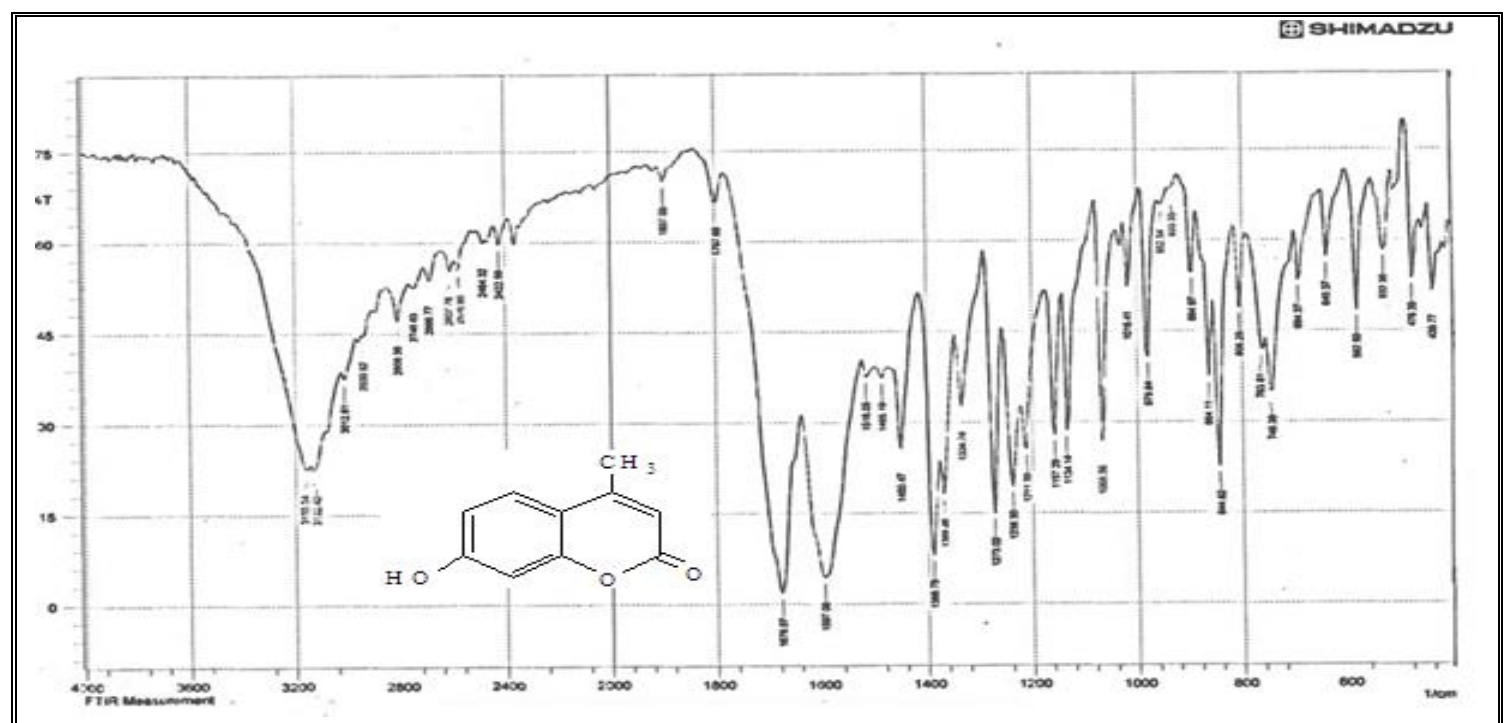

Fig. (1): FTIR Spectrum of Compound (1)

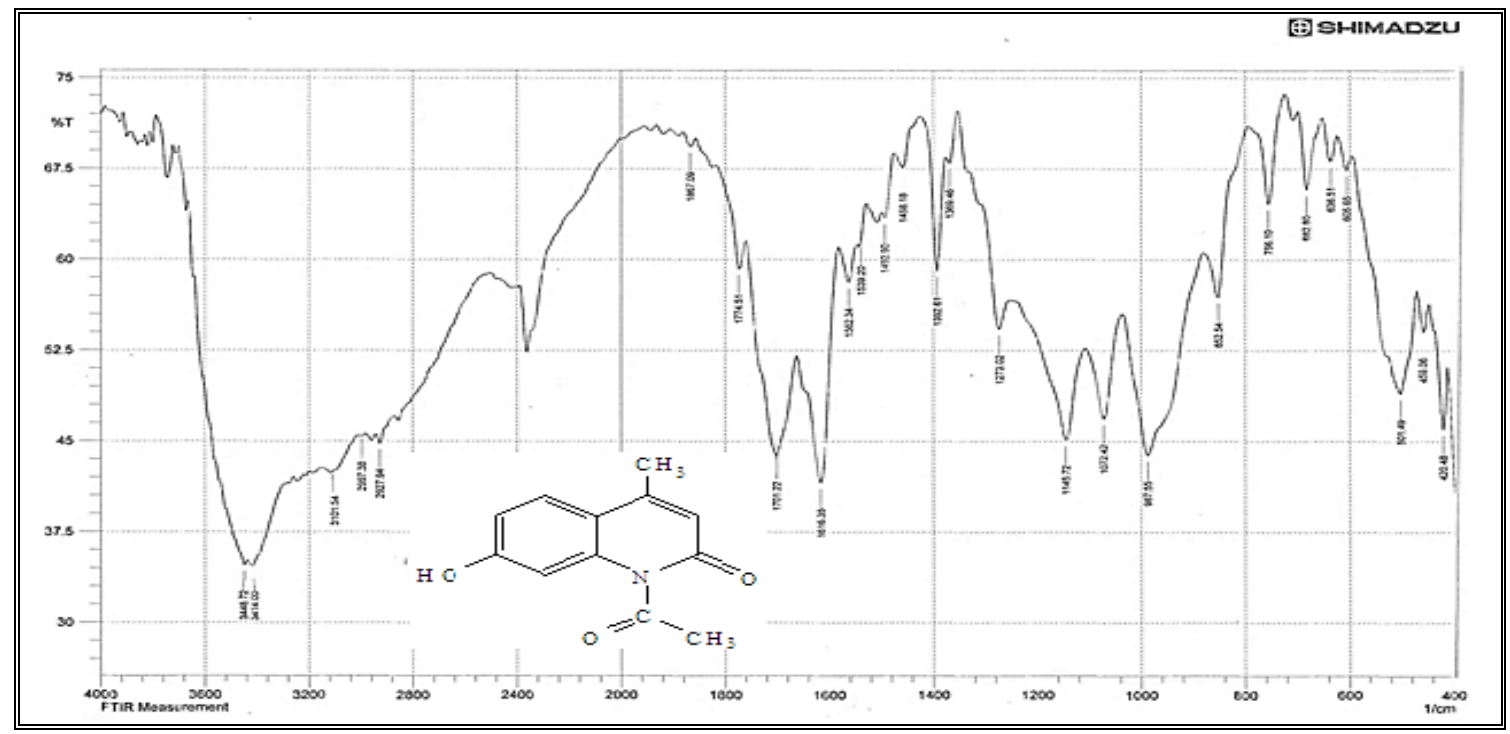

Fig. (2): FTIR Spectrum of Compound (2) 


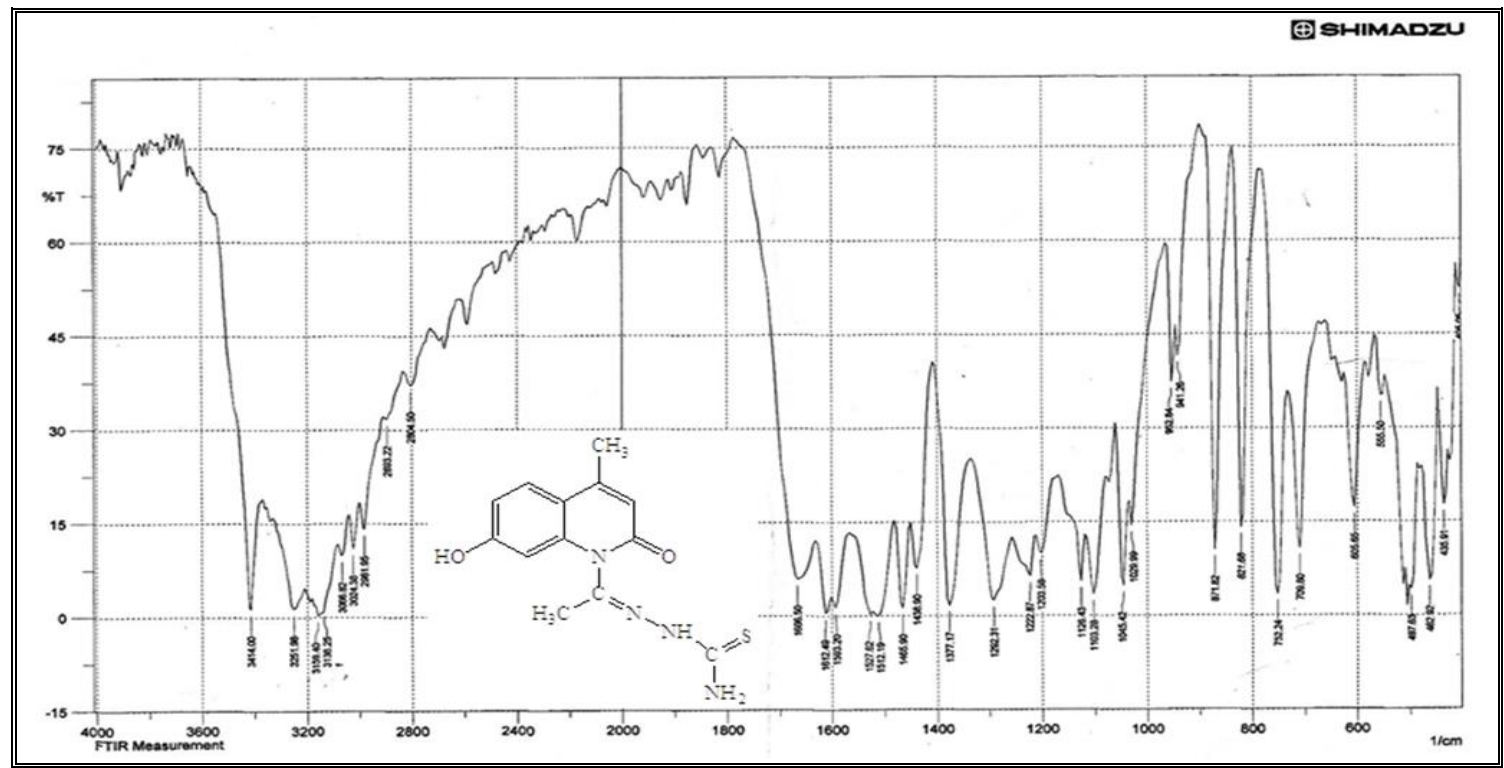

Fig. (3): FTIR Spectrum of Compound (3)

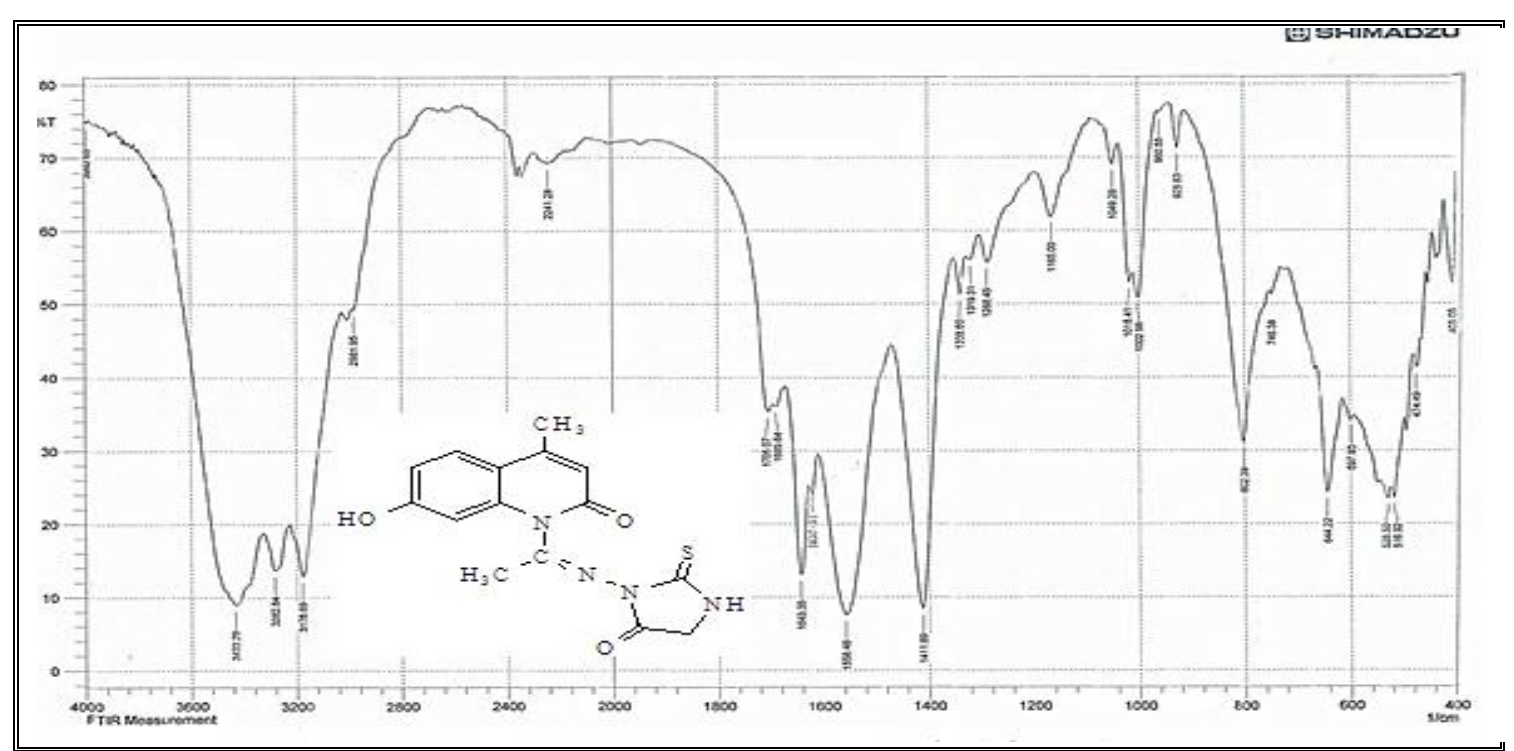

Fig. (4): FTIR Spectrum of Compound (4) 


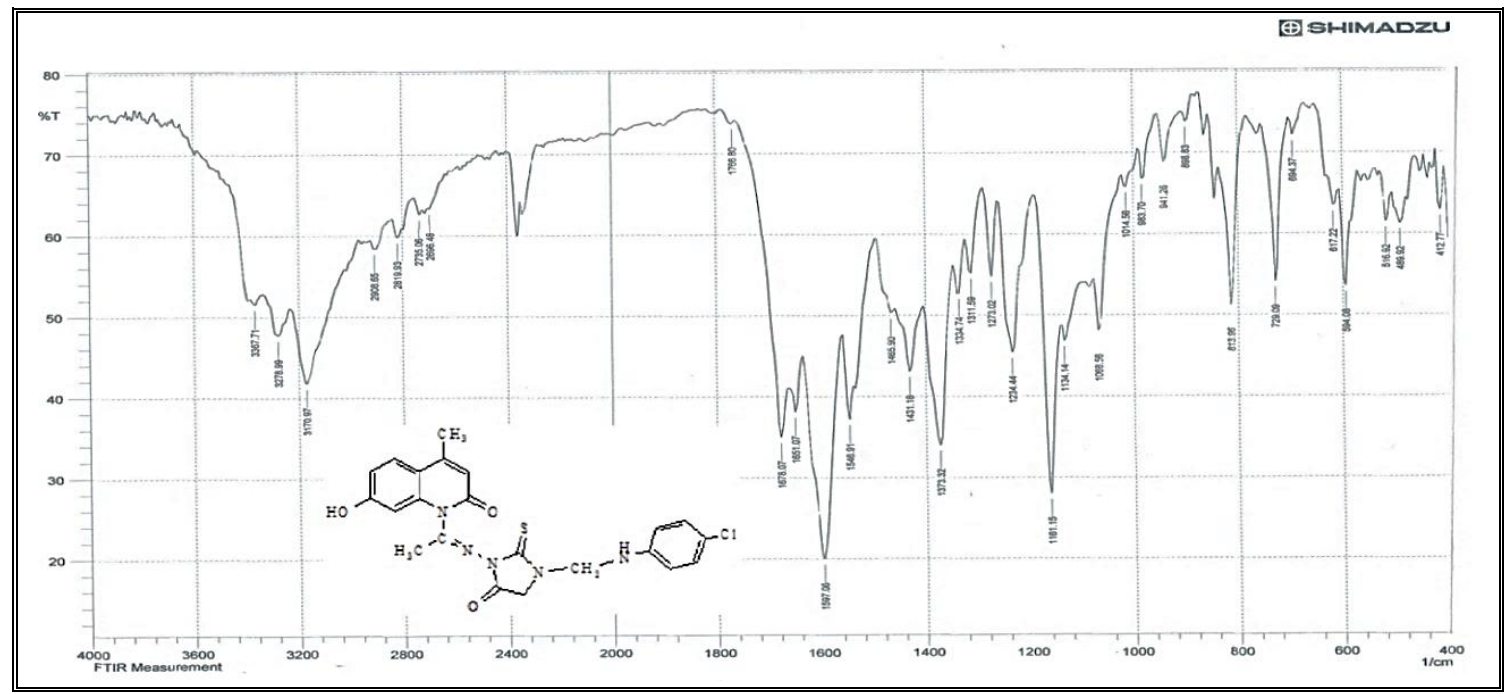

Fig. (5): FTIR Spectrum of Compound (6)

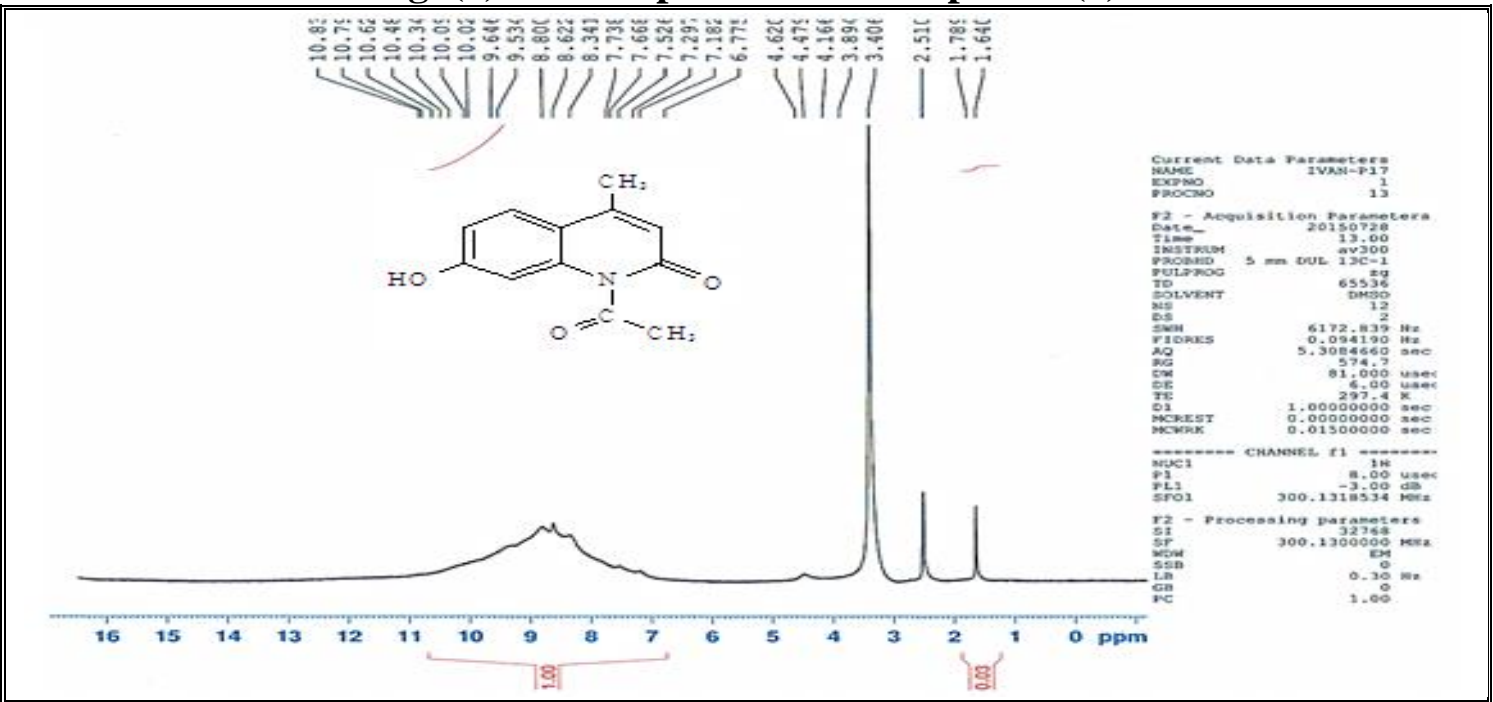

Fig. (6): ${ }^{1}$ HNMR Spectrum of Compound (2)

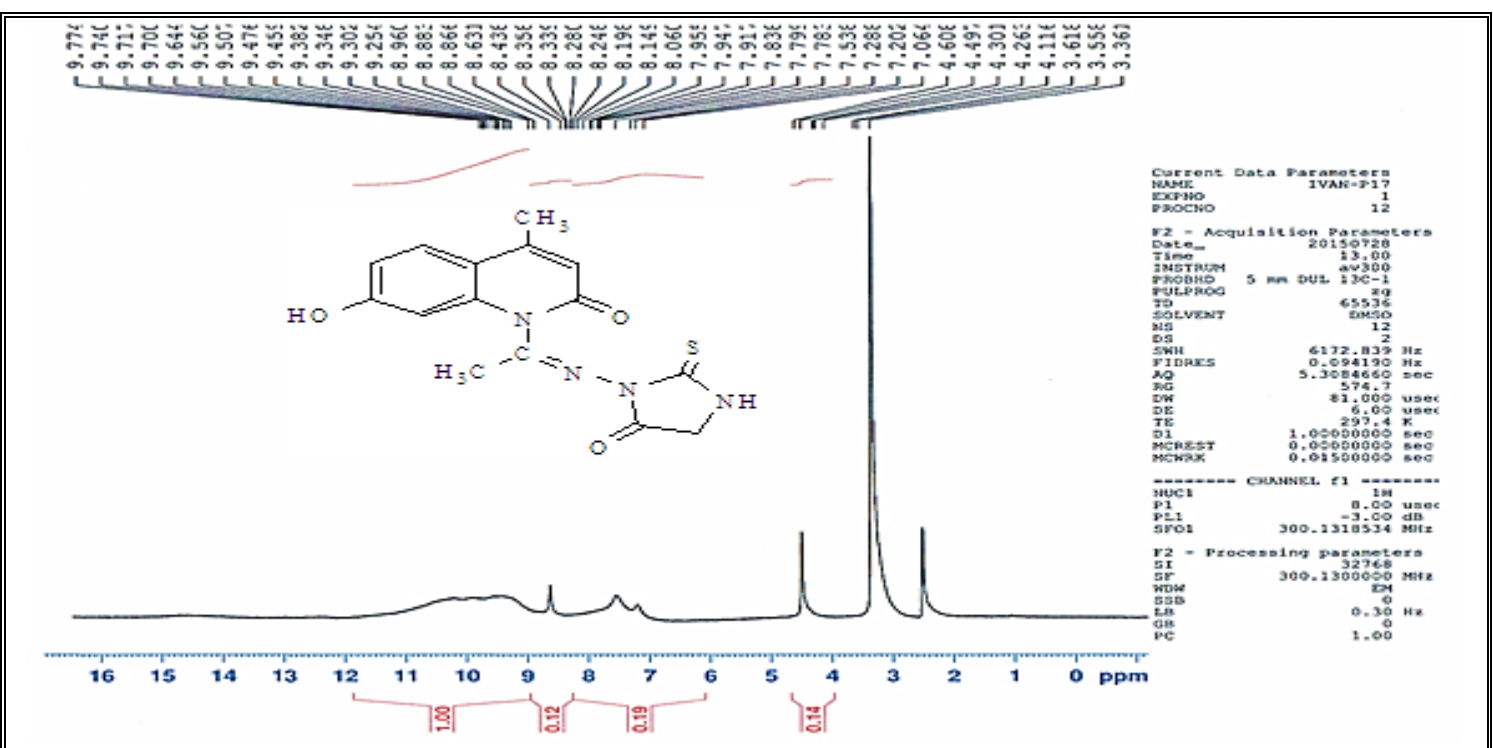

Fig. (7): ${ }^{1}$ HNMR Spectrum of Compound (4) 


\section{Target $0 @ 50^{\circ} \mathrm{C}$}

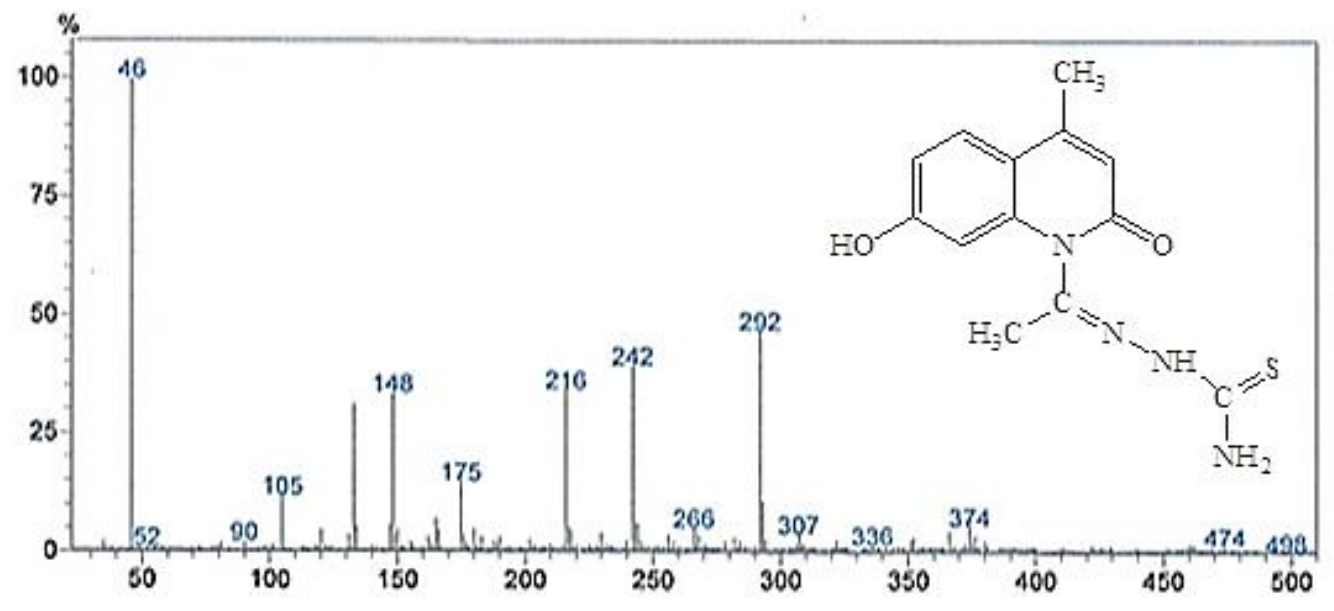

\section{References:}

[1] Ojala, T. 2001.Biological Screening of Plant Coumarins. Ph.D. Thesis, University of Helsinki, Helsinki, Finland.

[2] Bruneton, J. 1999. Pharmacognosy, Phytochemistry, Medicinal plants. Second Edition, Hampshire UK, Intercept Ltd; pp 263-277.

[3] Pelkonen, O.; Raunio, H.; Rautio, A.; Pasanen, M. and Lang, MA.1997. The Metabolism of Coumarin. Coumarins, Biology Applications and Mode of Action. (Eds: O'Kennedy R, Thornes RD), Chichester, Jhon Wiley \& sones; pp 67-92.

[4] AL-Azawi, K. F. S. 2013. Synthesis of New Heterocyclic Compounds Derived from 4-Methyl Coumarins. Ph. D. Thesis, chemistry Department, College of Science for Women, Baghdad University.

[5] Al-Bayati, R. I.; Al-Amiery, A. A. H. and Al-Majedy, Y. K.2010. Design, synthesis and bioassay of novel coumarins. Afr. J. Pure Appl. Chem. 4(6): 74-86.
[6] El-Hady, H. A. 2012. Syntheses and antimicrobial activity of some new thiohydantoin and thiazole derivatives. Der Pharma Chemica. 4(6): 2202-2207.

[7] Sindhu, T. J.; Meena, C.; David, P.; Bhat, A. R. and K. Krishnakumar. 2014." Comparitive Antitubercular Activity of Sulfadrug Subsitituted 1,4-Thiazines and 1,3-Thiazines". IJPRS. 3(1): 24-30.

[8] Urushima, T.; Ishikawa, H. and Hayashi,Y. 2011. "Asymmetric Mannich Reaction of Imines Derived from Aliphatic and Aromatic Aldehydes Catalyzed by Di aryl prolinol Silyl Ether". Chem.Eur.J. 17: 8273.

[9] Williams and Fleming. 1973. Spectroscopic Methodes in Organic Chemistry, 2nd Ed. , McGraw Hill, London.

[10] Robert Silverstien, M.; Francis Webster, X. and Daved Kiemle, J. 2005. Spectrometric Introduction of Organic Compounds, 7th Ed., John Wiley and Sons, USA. 
تحضير وتثخيص قواعد ماتخ جديدة مشتقة من 7-هيدروكسي-4-مثيل كومارين

ايناس سالم مهدي* (

عبدألامير مطلك فنجان

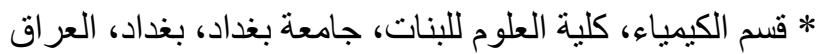

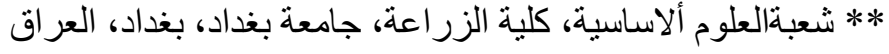

الكو مارين مادة طبيعية تستخلص من مختلف أنواع النباتات، تنتمي الى مجمو عة مركبات البنزوبايرون

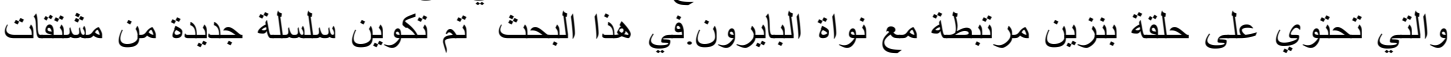

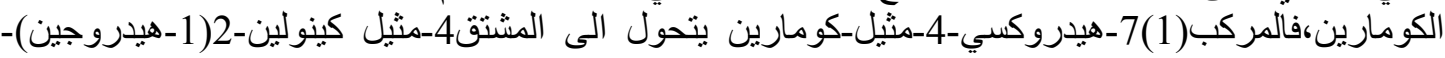

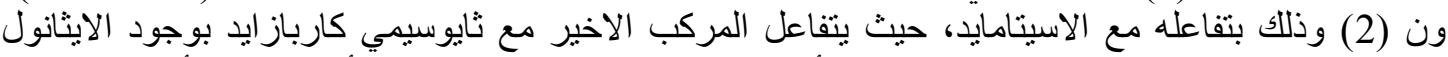

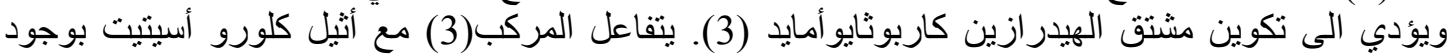

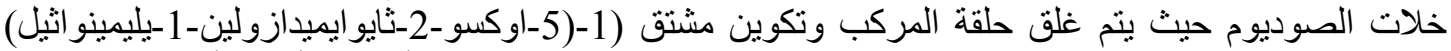
كينولين (4). ينم تحضير قو اعد مانخ من خلال تفاعل المركب(4) مع أمينات أولية أروماتية لتكوين

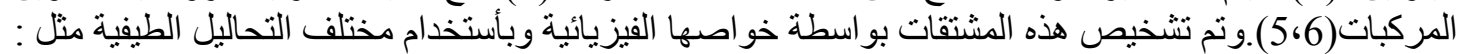
طيف الاشعة تحت الحمر اء ، وطيف الرنين النووي المغناطيسي وطيف الكتلة لبعض منها. الكلمات المفتاحية : كومارين ، ثايو أوكسو ايميدازولين ، مثيل كينولين. 